\title{
MYB-NFIB gene fusion in prostatic basal cell carcinoma: clinicopathologic correlates and comparison with basal cell adenoma and florid basal cell hyperplasia
}

\author{
Martin J. Magers ${ }^{1} \cdot$ Kenneth A. Iczkowski $^{2} \cdot$ Rodolfo Montironi $^{3} \cdot$ David J. Grignon $^{1} \cdot$ Shaobo Zhang ${ }^{1}$. \\ Sean R. Williamson $\mathbb{1}^{4,5} \cdot$ Ximing Yang $^{6} \cdot$ Mingsheng Wang $^{1} \cdot$ Adeboye O. Osunkoya $^{7}$ - Antonio Lopez-Beltran ${ }^{8,9}$. \\ Ondrej Hes $^{10} \cdot$ John N. Eble ${ }^{1} \cdot$ Liang Cheng ${ }^{1}$
}

Received: 31 January 2019 / Revised: 29 April 2019 / Accepted: 6 May 2019 / Published online: 12 June 2019

(c) United States \& Canadian Academy of Pathology 2019

\begin{abstract}
Prostatic basal cell carcinoma is a malignant neoplasm composed of basaloid cells forming infiltrative nests and tubules, which may potentially be misdiagnosed as benign basal cell proliferations (i.e., florid basal cell hyperplasia or basal cell adenoma) and also closely resembles adenoid cystic carcinoma of the salivary gland. MYB-NFIB gene rearrangement occurs in 30-86\% of salivary gland adenoid cystic carcinomas. We sought to further characterize $M Y B$ gene rearrangement in prostatic basal cell carcinoma and correlate $M Y B-N F I B$ fusion status with other clinicopathologic characteristics. To this end, FISH analysis for MYB-NFIB gene fusion using fusion probes was performed on formalin-fixed, paraffin-embedded tissue sections from prostatic basal cell carcinoma $(n=30)$, florid basal cell hyperplasia $(n=18)$, and basal cell adenoma $(n=4)$. Fourteen of 30 (47\%) cases of basal cell carcinoma were positive for MYB-NFIB gene fusion FISH, and no cases of benign basal cell proliferations were positive $(p<0.05)$. FISH-positive patients (mean age $=63$ years, range: $35-81)$ tended to be younger than FISH-negative patients (mean age $=70$ years, range: 55-93). Most FISH-positive cases demonstrated adenoid cystic carcinoma-like morphology (57\%), and most FISH-negative cases demonstrated nonadenoid cystic carcinoma-like morphology (93\%); one case (FISH-positive) demonstrated areas with both adenoid cystic carcinoma-like and nonadenoid cystic carcinoma-like morphology. FISH-positive cases more frequently demonstrated perineural invasion (50\% vs. $14 \%$, $p<0.05)$ compared to FISH-negative cases. Conversely, tall basal cells (i.e., neoplastic cells at least two times taller than wide) were more frequent in FISH-negative cases than FISH-positive cases (93\% vs. 36\%, $p<0.05$ ). Approximately, $50 \%$ of prostatic basal cell carcinoma harbor MYB-NFIB gene fusion. The majority of these cases were characterized by adenoid cystic carcinoma-like morphology, perineural invasion, and lack tall basal cells. Florid basal cell hyperplasia and basal cell adenoma are negative for $M Y B-N F I B$ gene fusion.
\end{abstract}

$\triangle$ Liang Cheng

liang_cheng@yahoo.com

1 Department of Pathology and Laboratory Medicine, Indiana University School of Medicine, Indianapolis, IN, USA

2 Department of Pathology, Medical College of Wisconsin, Milwaukee, WI, USA

3 Institute of Pathological Anatomy and Histopathology, School of Medicine, Polytechnic University of the Marche Region and United Hospitals, Ancona, Italy

4 Department of Pathology and Laboratory Medicine and Henry Ford Cancer Institute, Henry Ford Health System, Detroit, MI, USA
5 Departmentof Pathology, Wayne State University School of Medicine, Detroit, MI, USA

6 Department of Pathology, Northwestern University, Chicago, IL, USA

7 Departments of Pathology and Urology, Emory University, Atlanta, GA, USA

8 Department of Pathology, Cordoba University Faculty of Medicine, Cordoba, Spain

9 Champalimaud Clinical Center, Lisbon, Portugal

10 Department of Pathology, Charles University Hospital Plzeň, Pilsen, Czech Republic 


\section{Introduction}

Prostatic basal cell carcinoma is a rare, malignant neoplasm composed of prostatic basal cells and was first reported in the literature by Frankel and Craig [1] more than 40 years ago. Morphologically, prostatic basal cell carcinoma is comprised of basaloid cells forming infiltrative nests and tubules, and this may closely mimic adenoid cystic carcinoma of the salivary gland and other sites. In fact, many prostatic basal cell carcinomas in the literature were previously considered prostatic adenoid cystic carcinoma, and this was a distinct tumor entity until it was absorbed into the category of prostatic basal cell carcinoma in subsequent WHO classifications scheme [2]. On the other hand, florid basal cell hyperplasia and basal cell adenoma may also mimic basal cell carcinoma, although basal cell hyperplasia and basal cell adenoma are benign. Thus, distinction of basal cell carcinoma from these benign basal cell proliferations is critical.

Fewer than 100 cases of prostatic basal cell carcinoma have been reported in the literature, with most being case reports [1,3-17]. This paucity of information regarding prostatic basal cell carcinomas leaves many unanswered questions about this interesting neoplasm. In particular, relatively little is known regarding the molecular underpinnings of prostatic basal cell carcinoma. Recently, it was demonstrated that prostatic basal cell carcinomas lack TMPRSS2-ERG gene fusion and may harbor EGFR and/or $P T E N$ abnormalities, while another group demonstrated $M Y B$ gene rearrangement [assessed using a fluorescence in situ hybridization (FISH) break-apart probe] in a subset of prostatic basal cell carcinomas $[5,16]$.

The presence of $M Y B$ gene rearrangements in a subset of prostatic basal cell carcinomas is particularly interesting, considering the existence of adenoid cystic carcinoma-like morphology within the spectrum of prostatic basal cell carcinoma. Salivary gland adenoid cystic carcinomas often possess MYB-NFIB gene fusion, and MYB-NFIB gene fusion, $M Y B$ amplification, and $M Y B L 1$ rearrangements have also been identified in adenoid cystic carcinoma of other sites [18-23]. The MYB gene is located on chromosome 6, and the NFIB gene is located on chromosome 9, with the fusion gene resulting from a $t(6 ; 9)$ translocation. This translocation results in overexpression of $M Y B$ through deletion of target sites, which repress $M Y B$ expression. This, in turn, activates MYB targets [24-26]. Thus, the presence of $M Y B$ gene rearrangements in prostatic adenoid cystic carcinoma-like basal cell carcinoma may suggest that prostatic adenoid cystic carcinoma is truly a distinct entity rather than part of the prostatic basal cell carcinoma morphologic spectrum, and analysis for a $M Y B$ gene rearrangement may be a useful tool to identify these tumors. Furthermore, if prostatic benign basal cell proliferations lack $M Y B$ gene rearrangements, ancillary testing for $M Y B$ gene rearrangements may be useful in difficult cases. Thus, we sought to further characterize $M Y B$ gene rearrangements in prostatic basal cell carcinoma and correlate $M Y B$ gene status with morphologic findings.

\section{Materials and methods}

\section{Patients}

Thirty cases of prostatic basal cell carcinoma with material available for FISH analysis were collected from the surgical pathology archives of the participating institutions. The diagnosis of prostatic basal cell carcinoma was rendered based on accepted histomorphologic features [2]. Representative hematoxylin and eosin-stained slides were reviewed for morphologic characterization. In addition, 18 cases of florid basal cell hyperplasia and 4 cases of basal cell adenoma were included in FISH analysis. The prostatic basal cell carcinoma cases consisted of material from a transrectal core needle biopsy $(n=1)$, transurethral resections of the prostate $(n=18)$, and radical prostatectomies $(n=11)$. Similarly, the basal cell hyperplasia cases consisted of material from transurethral resections of the prostate $(n=16)$ and radical prostatectomies $(n=2)$; all four cases of basal cell adenoma were from radical prostatectomies. Demographic and clinical information was obtained from medical records or from the submitting pathologist. This study was approved by the Institutional Review Board.

The hematoxylin and eosin-stained slides of 28 cases were reviewed and assessed for the following morphologic features: tall basal cells (i.e., at least two times taller than wide), cribriform architecture, well-formed lumina, necrosis, infiltrative growth, stromal desmoplasia, mitotic figures, perineural invasion, psammoma bodies, and extraprostatic extension. Each case was also generally categorized as having either adenoid cystic carcinoma-like morphology (e.g., cribriform architecture with extracellular hyaline-like material and basaloid neoplastic cells) or nonadenoid cystic carcinoma-like morphology based on the overall morphologic features of the tumor. This review was blinded to the FISH results, such that knowledge of $M Y B$ gene status could not influence assessment of morphologic features.

\section{Fluorescence in situ hybridization}

FISH analysis for $M Y B-N F I B$ gene fusion using fusion probes was performed on $4 \mathrm{~mm}$ sections of the corresponding formalin-fixed, paraffin-embedded tissue. The FISH assays were performed according to a previously described protocol [5, 18, 19]. The slides were 
deparaffinized and treated with $0.1 \mathrm{mM}$ of citrate buffer $(\mathrm{pH}$ 6.0) (Zymed, San Francisco, California, USA) at $95^{\circ} \mathrm{C}$ for $10 \mathrm{~min}$. The tissue was then digested with $400 \mu \mathrm{L}$ of pepsin $(5 \mathrm{mg} / \mathrm{mL}$ in $0.01 \mathrm{~N}$ hydrochloric acid with $0.9 \% \mathrm{NaCl}$; Sigma, St. Louis, MO, USA) at $37^{\circ} \mathrm{C}$ for $40 \mathrm{~min}$ in a humidified chamber. The MYB-NFIB fusion $[t(6 ; 9)(\mathrm{q} 22-23$; p23-24)] probe cocktail contains bacterial artificial chromosome clones RP11-104D9-Orange [chr6: 135,408,214-135,589,039] and RP11-54D21-Green [chr9:14,158,320-14,324,079] (Empire Genomics, Buffalo, New York) [18, 24, 27] (Fig. 1).

The probes were diluted with tDenHyb2 to a ratio of 1:25. The slides were denatured at $80^{\circ} \mathrm{C}$ for $10 \mathrm{~min}$ and hybridized at $37^{\circ} \mathrm{C}$ overnight. The slides were washed twice with $0.1 \times$ saline-sodium citrate (SSC) $/ 1.5$ moles urea solution at $45^{\circ} \mathrm{C}$ for $20 \mathrm{~min}$ each. The slides were then washed with $2 \times \mathrm{SSC}$ and $2 \times \mathrm{SSC} / 0.1 \% \mathrm{NP} 40$ each for $10 \mathrm{~min}$ at $45^{\circ} \mathrm{C}$. The slides were counterstained with 4,6 diamidino-2-phenylindole (Insitus Biotechnologies, Albuquerque, NM, USA). The slides were examined with a Zeiss Axioplan 2 microscope (Ziess, Gottingen, Germany) using the following filters: SP-100, MF-101 for Spectrum Green and Gold 31003 for Spectrum Orange (Chroma, Brattleboro, VT, USA). The slides were analyzed with Isis software (MetaSystem, Belmont, MA, USA). Four sequential focus stacks with $0.3 \mathrm{~mm}$ intervals were acquired. The Isis software then integrated the stacks automatically into a single image in order to reduce thickness-related artefacts.

Evaluation and analysis of the cases were carried out by two pathologists, independently. Between 100 and 200 nonoverlapping cancer cell nuclei were evaluated for each case [28-30]. Preparations were considered valid if $>90 \%$ of the cells showed bright signals. Wild-type chromosomes showed well-separated green $(N F I B)$ and red $(M Y B)$ signals. A case was considered positive if $\geq 15 \%$ of cells exhibited at least one $5^{\prime} M Y B-3^{\prime} N F I B$ fusion signal [21, 31]. FISH analysis was repeated in select cases to confirm the result, and the same result was obtained; this did not affect the final result of any cases.

\section{Results}

Fourteen of $30(47 \%)$ cases of basal cell carcinoma were positive for MYB-NFIB gene fusion FISH (Figs. 2 and 3; $p$ $<0.05)$. The gene fusion signals were distributed evenly throughout the malignant cells, and no gene fusions were present in adjacent benign glands. FISH-positive patients (mean age $=63$ years, median age $=66$ years, range: 35-81) tended to be younger than FISH-negative patients (mean age $=70$ years, median age $=69.5$ years, range: $55-93)$
The morphologic features are summarized in Table 1 and fully detailed in Table 2 . Of the 28 cases available for review, 9 were classified as adenoid cystic carcinoma-like, 18 were classified as nonadenoid cystic carcinoma-like, and 1 case had striking features of both morphologic patterns. Most FISH-positive cases demonstrated adenoid cystic carcinoma-like morphology in at least part of the tumor $(n=9,57 \%$, Fig. 3a), and most FISH-negative cases demonstrated nonadenoid cystic carcinoma-like morphology $(n=13,93 \%)$; the single case with both adenoid cystic carcinoma-like and basal cell carcinoma-like morphologic patterns was FISH positive.

Although morphology usually correlated with FISH status, this was not true in all cases, as some FISH-positive cases were nonadenoid cystic carcinoma-like, while some FISH-negative cases were adenoid cystic carcinoma-like. FISH-positive cases more frequently demonstrated perineural invasion (Fig. $3 b ; 50 \%$ vs. $14 \%, p$ value $<0.05$ ) compared to FISH-negative cases. Conversely, tall basal cells (i.e., neoplastic cells at least two times taller than wide) were more frequent in FISH-negative cases than FISHpositive cases (Fig. 4; 93\% vs. 36\%, $p<0.05$ ). Regarding the remaining morphologic parameters, significant overlap was present between the FISH-positive and the FISHnegative cases.

All cases of florid basal cell hyperplasia $(n=18)$ and basal cell adenoma $(n=4)$ were negative for MYB-NFIB gene fusion (Fig. 5).

\section{Discussion}

In the present study, approximately half of prostatic basal cell carcinoma harbor $M Y B-N F I B$ gene fusion. To the authors' knowledge, ours is the first study to definitively demonstrate $M Y B-N F I B$ gene fusion in prostatic basal cell carcinoma. Recently, Bishop et al. [5] identified a $M Y B$ rearrangement in 2 of 7 (29\%) prostatic basal cell carcinomas with adenoid cystic carcinoma-like morphology using break-apart FISH probes. This study by Bishop et al. served as the molecular basis for our study, though we utilized fusion, rather than break-apart, FISH probes to not only demonstrate a $M Y B$ rearrangement but also confirm that the fusion partner is $N F I B$, resulting in the expected $M Y B-N F I B$ gene fusion. Similar to Bishop et al., which studied seven cases of prostatic basal cell carcinoma with adenoid cystic carcinoma-like morphology (i.e., cribriform architecture) and five cases of prostatic basal cell carcinoma which demonstrated a predominantly solid rather than cribriform growth pattern (i.e., considered nonadenoid cystic carcinoma-like in our study), we also identified distinct morphologic patterns in prostatic basal cell carcinoma. Our FISH results are in accordance with theirs, in which the 


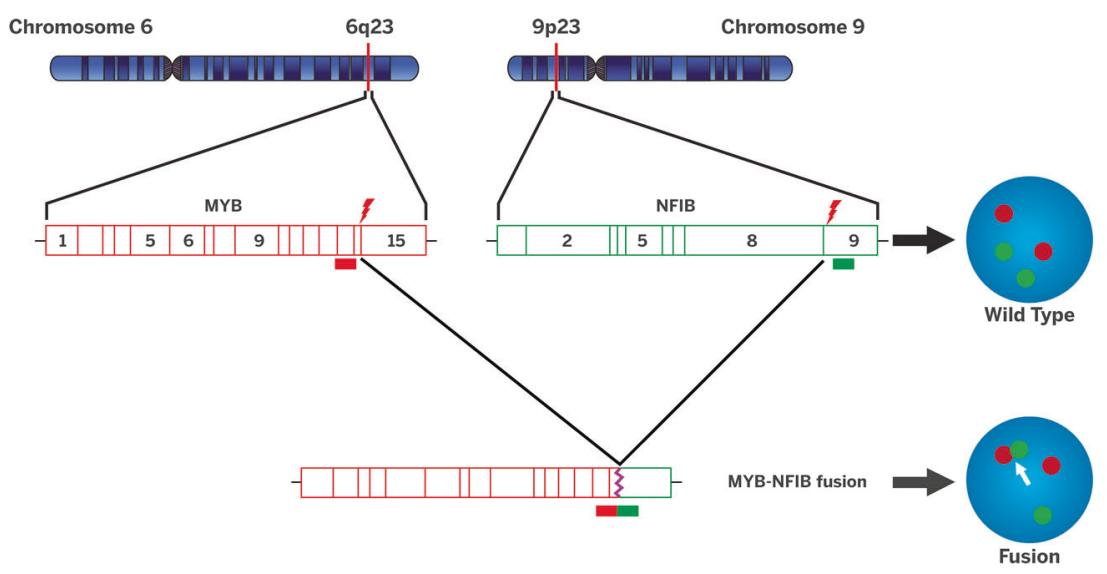

Fig. 1 Schematic illustration of the $M Y B-N F I B$ gene fusion detection. The $t(6 ; 9)$ translocation results in a $M Y B-N F I B$ gene fusion. The dualcolor fusion FISH probe set uses the BAC clones RP11-104D9 (MYB, red) and RP11-54D21 (NFIB, green) which adhere to the 5' portion of
$M Y B$ and the $3^{\prime}$ portion of $N F I B$, approximating the translocation breakpoints. A wild-type cell demonstrates well-separated green and red signals, whereas a cell harboring $M Y B-N F I B$ gene fusion demonstrates a fused red-green signal
Fig. 2 Prostatic basal cell carcinoma is typically composed of relatively bland neoplastic basaloid cells, but the low power architecture of prostatic basal cell carcinoma varies considerably. Large cribriform structures admixed with hyaline material (a), haphazardly arranged nests of varying sizes (b), large nests and trabeculae (c), and solid sheets with scattered lumens (d) may all be seen on low power evaluation. The malignant nature of prostatic basal cell carcinoma can sometimes be confirmed by the presence of small, infiltrative nests and tubules (e), or the presence of extraprostatic extension (f)

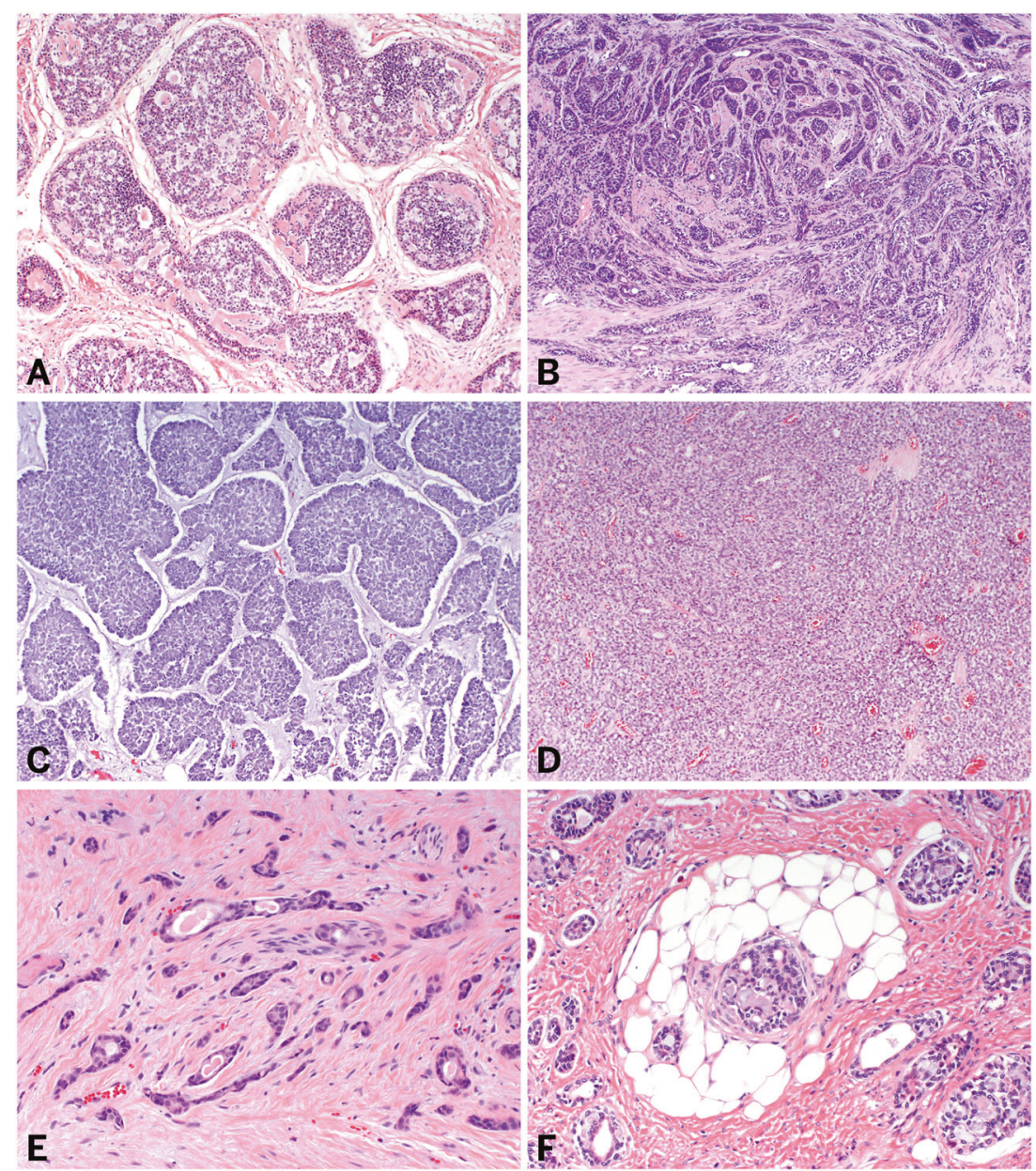

adenoid cystic carcinoma-like morphology is enriched for $M Y B$ gene rearrangements; however, unlike Bishop et al. we did identify one case of prostatic basal cell carcinoma with nonadenoid cystic carcinoma-like morphology which harbored a MYB-NFIB gene fusion. Interestingly, the incidence of $M Y B$ gene rearrangement in the study by Bishop 
Fig. 3 Approximately, half $(47 \%)$ of the prostatic basal cell carcinoma were positive for $M Y B-N F I B$ gene fusion FISH, and most FISH-positive cases demonstrated morphologic cystic carcinoma (a),

characterized by basaloid neoplastic cells in cribriform architecture with extracellular hyaline-like material. Perineural invasion was associated with FISH-positive cases (b). FISH analysis for $M Y B-N F I B$ gene fusion was performed using fusion probes, and a positive FISH result was defined as at least $15 \%$ of cells exhibiting a 5'-MYB-3'-NFIB fusion (c, arrow points to gene fusion). Morphologic features were not entirely predictive of genomic status, as a subset of FISHnegative cases rarely demonstrated adenoid cystic carcinoma-like features. In the same vein, most FISH-negative cases demonstrated nonadenoid cystic carcinoma-like morphologic features $(\mathbf{d}, \mathbf{e})$, and a subset of FISH-positive cases were also nonadenoid cystic carcinoma-like (f) features reminiscent of adenoid
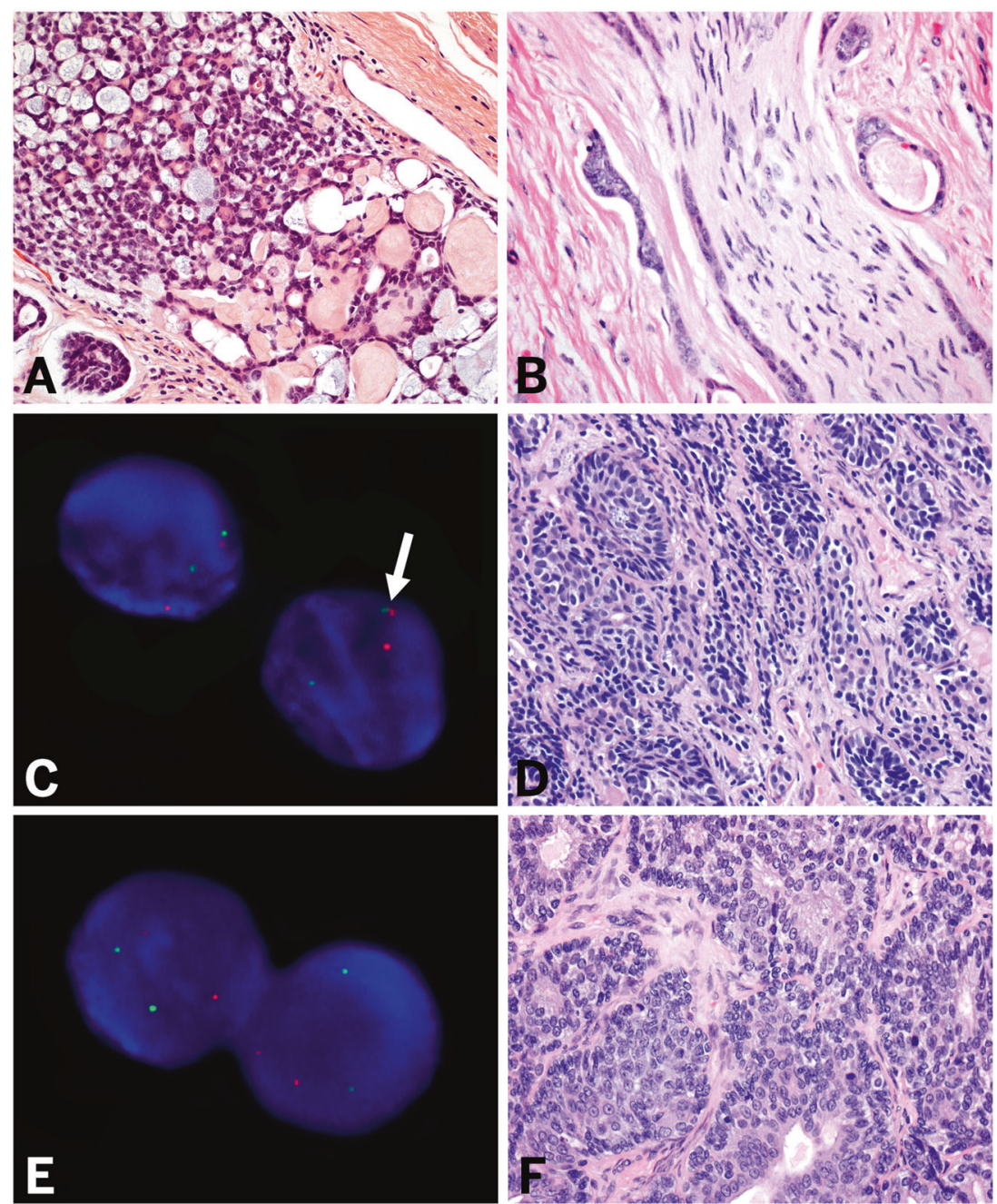

Table 1 Summarized

clinicopathologic and morphologic characteristics ${ }^{\mathrm{a}}$

\begin{tabular}{llll}
\hline & & MYB-NFIB gene fusion & MYB-NFIB gene fusion \\
& FISH-positive BCC $(n=14)$ & FISH-negative BCC $(n=14)$ \\
\hline \multirow{3}{*}{$\begin{array}{lll}\text { Histologic } \\
\text { parameters }\end{array}$} & Age (mean, range) & 63 years $(35-81)$ & 70 years $(55-93)$ \\
& ACC-like & $57 \%{ }^{\mathrm{b}}$ & $7 \%$ \\
& Non-ACC-like & $36 \% \%^{\mathrm{b}}$ & $93 \%$ \\
& Perineural Invasion $(p$ value $<$ & $50 \%$ & $14 \%$ \\
& $0.05)$ & & \\
& Tall basal cells $(p$ value $<0.05)$ & $36 \%$ & $93 \%$ \\
& Cribriform architecture & $64 \%$ & $7 \%$ \\
& Well-formed lumina & $43 \%$ & $57 \%$ \\
& Necrosis & $0 \%$ & $14 \%$ \\
& Infiltrative growth & $100 \%$ & $100 \%$ \\
& Stromal desmoplasia & $7 \%$ & $7 \%$ \\
Mitotic figures & $43 \%$ & $36 \%$ \\
& Psammoma bodies & $14 \%$ & $7 \%$ \\
& Extraprostatic extension & \\
& & 5 of 8 cases & 3 of 6 cases \\
\hline
\end{tabular}

${ }^{a}$ Two cases contained insufficient material for a complete morphologic review

${ }^{\mathrm{b}}$ One case $(7 \%)$ which was FISH-positive demonstrated both ACC-like and non-ACC-like areas

${ }^{c}$ Extraprostatic extension was not able to be evaluated in all cases due to some cases being diagnosed via transurethral resection

$A C C$ adenoid cystic carcinoma 


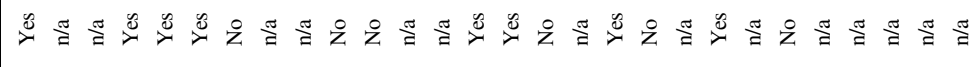

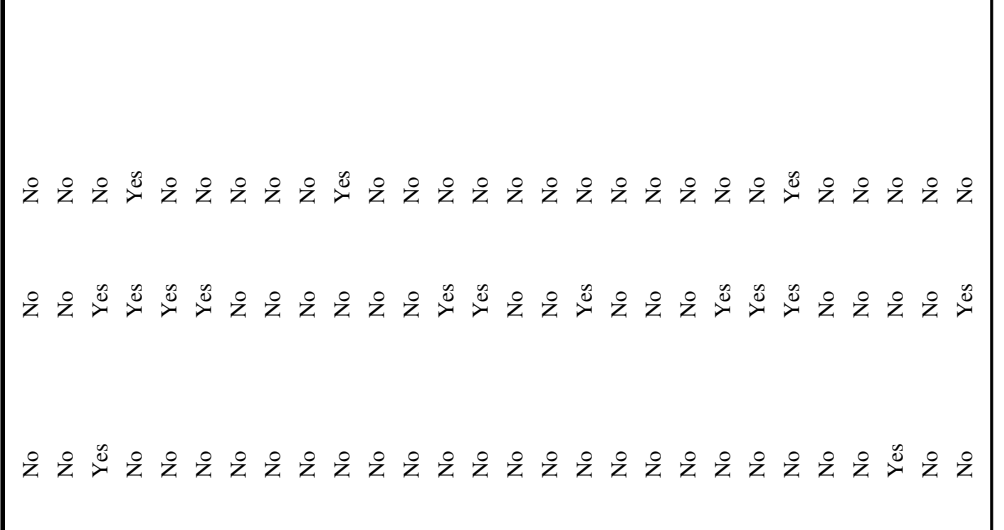

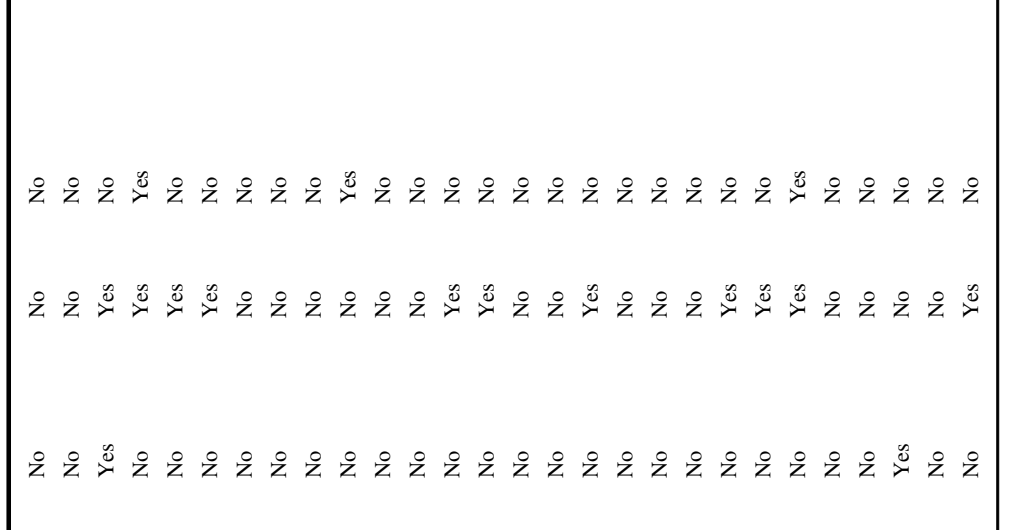

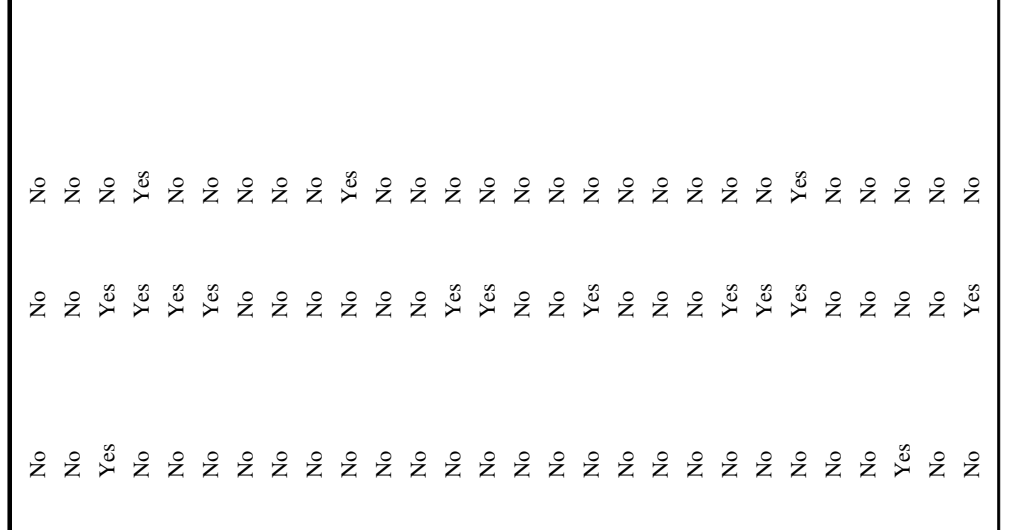

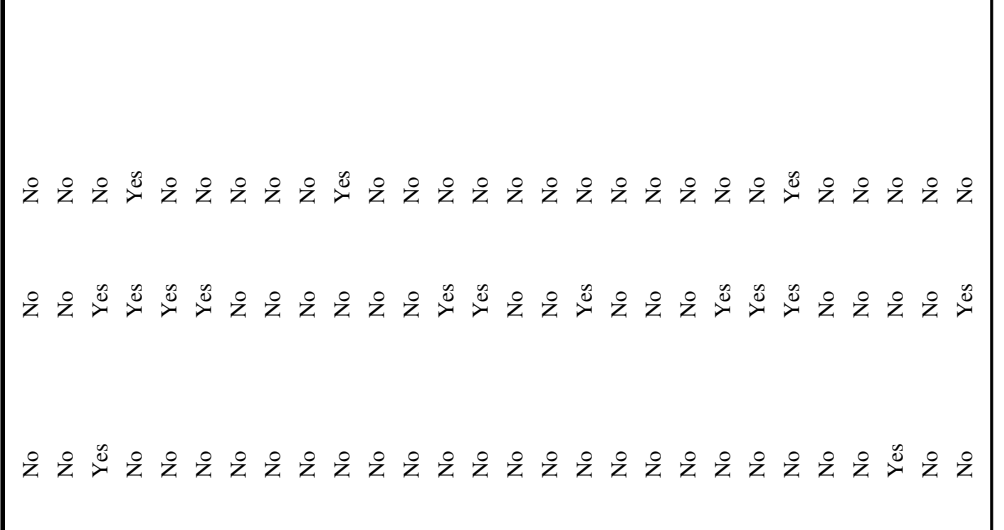

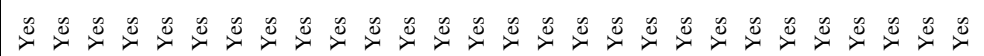

产

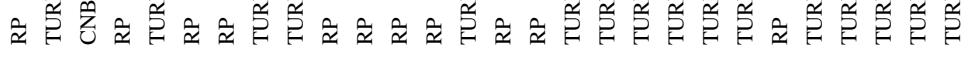

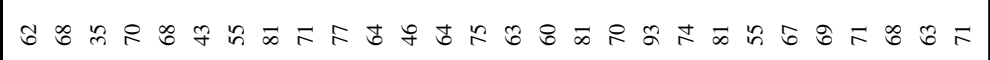
(5)

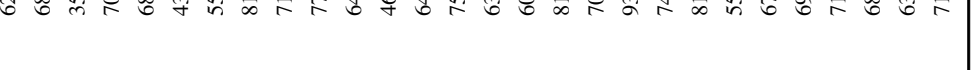


Fig. 4 The presence of tall basal cells, defined as at least two times taller than wide (a), were present in nearly all FISHnegative cases (b), while they were absent in most FISHpositive cases. In contrast, perineural invasion (c) was more frequently identified in FISHpositive cases (d, arrow points to gene fusion) than in FISHnegative cases
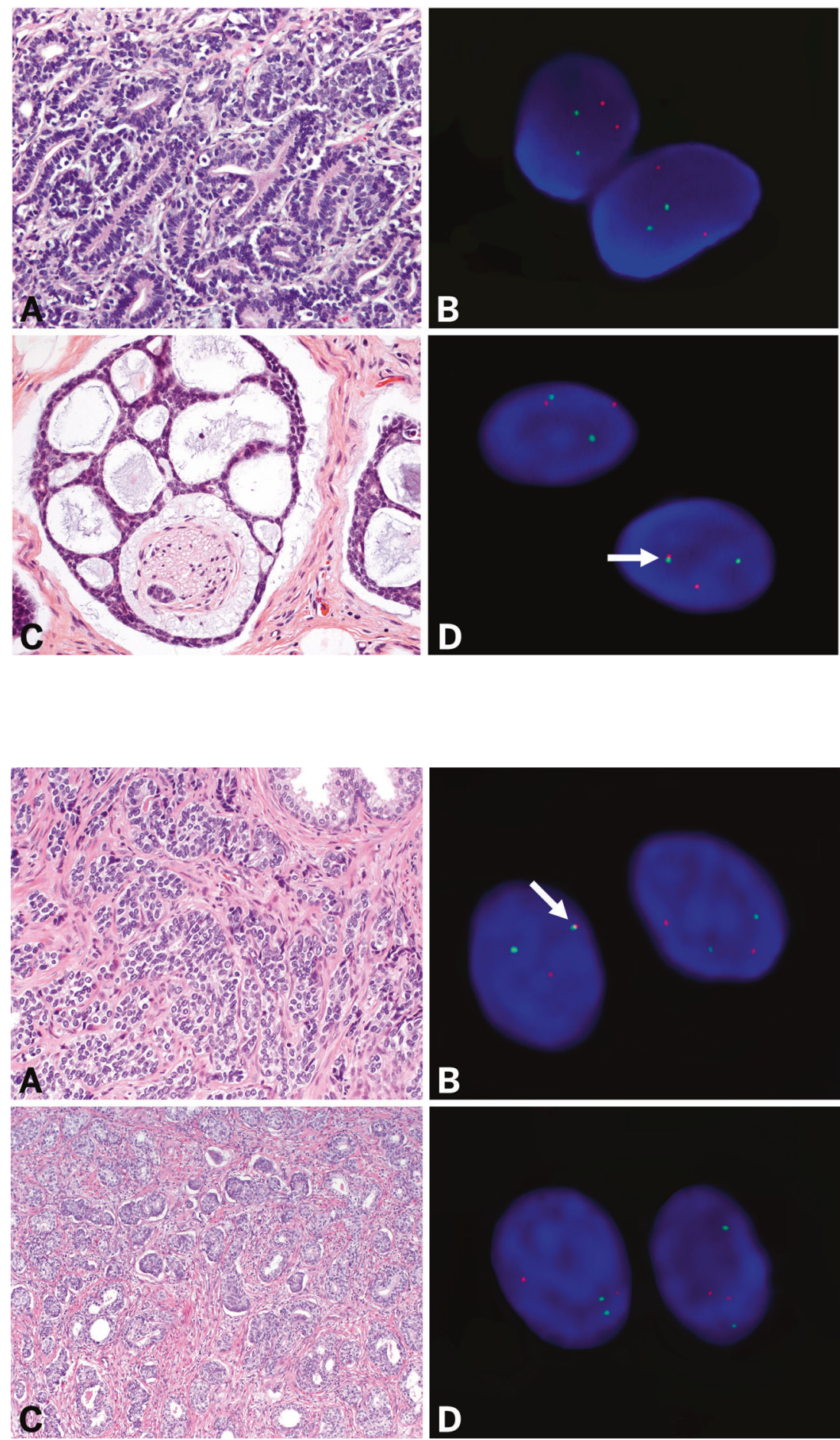

Fig. 5 Whereas approximately half of prostatic basal cell carcinoma (a) harbors $M Y B$ $N F I B$ gene fusion (b), florid basal cell hyperplasia (c) and basal cell adenoma were all negative for $M Y B-N F I B$ gene fusion (d). Because prostatic basal cell carcinoma and benign basal cell proliferations may closely resemble one another, FISH analysis for $M Y B-N F I B$ may be useful in this differential diagnosis. A positive-FISH result would weigh heavily in favor of prostatic basal cell carcinoma et al. was 29\% ( 2 of 7 cases) in cases with adenoid cystic carcinoma-like morphology, $0 \%$ ( 0 of 5 cases) in cases with nonadenoid cystic carcinoma-like morphology, and overall $17 \%$ ( 2 of 12 cases) in all cases of prostatic basal cell carcinoma included in the study, which is notably lower than the incidence of $M Y B-N F I B$ gene fusion in our study (89\% in cases with adenoid cystic carcinoma-like morphology, $47 \%$ overall). The reasons for this disagreement of incidence are not entirely clear. Ours is the largest study of $M Y B$ gene rearrangements in prostatic basal cell carcinoma ( $n=30$ cases), and this is more than twice the number of cases included in the study by Bishop et al.; this may be a factor in the apparent disagreement in incidence between the two studies. In summary, it is clear that a subset of what is currently considered prostatic basal cell carcinoma harbor $M Y B-N F I B$ gene rearrangements, and this gene fusion is 
more frequently found in cases with morphology reminiscent of adenoid cystic carcinoma. Whether these cases should be considered as a separate entity (i.e., prostatic adenoid cystic carcinoma rather than basal cell carcinoma) is unclear, but this distinction may become relevant in the future if prognostic or therapeutic differences become apparent (e.g., if a targeted therapy for $M Y B$ gene rearrangement is developed).

Regardless of whether prostatic basal cell carcinoma with $M Y B-N F I B$ gene fusion is a distinct entity, it is notable that $M Y B$ gene rearrangements have not been described in benign basal cell proliferations of the prostate (i.e., basal cell hyperplasia or basal cell adenoma). Indeed, all 18 cases of basal cell hyperplasia and basal cell adenoma subjected to FISH analysis in our study were negative for $M Y B-N F I B$ gene fusion. Prostatic basal cell carcinoma may be difficult to distinguish from benign basal cell proliferations in some cases, particularly in cases with limited material in which features of invasion may not be apparent. Our study suggests that FISH analysis for MYB gene rearrangement may be of clinical utility in these difficult cases, as a positive result would weigh heavily in favor of prostatic basal cell carcinoma rather than a benign process. Nonetheless, because only half of the prostatic basal cell carcinoma in our study harbored MYB-NFIB gene fusion, a negative result would not exclude the possibility of prostatic basal cell carcinoma.

Several limitations of this study should be noted. This was a retrospective study. Morphologic criteria for prostatic basal cell proliferations, including prostatic basal cell carcinoma, have evolved. We cannot absolutely exclude the possibility that some MYB-NFIB gene fusion negative cases of prostatic basal cell carcinoma may have been misdiagnosed as prostatic carcinoma, which again emphasizes the clinical utility of molecular testing in difficult cases. In addition, because clinical outcome was not an aim of this study, it is not known whether the MYB-NFIB is associated with clinical outcome, and this should be an aim of future studies.

In conclusion, we identified $M Y B-N F I B$ gene fusion in approximately half of prostatic basal cell carcinoma in a relatively large cohort of these tumors, and no cases of benign prostatic basal cell proliferations harbored this fusion. Cases with $M Y B-N F I B$ gene fusion often had morphologic features reminiscent of adenoid cystic carcinoma. Further studies are required to determine whether prostatic basal cell carcinoma with $M Y B-N F I B$ should be considered an entity separate from prostatic basal cell carcinoma without $M Y B$ gene rearrangements.

\section{Compliance with ethical standards}

Conflict of interest The authors declare that they have no conflict of interest.
Publisher's note: Springer Nature remains neutral with regard to jurisdictional claims in published maps and institutional affiliations.

\section{References}

1. Frankel K, Craig JR. Adenoid cystic carcinoma of the prostate. Report of a case. Am J Clin Pathol. 1974;62:639-45.

2. Montironi R, Epstein JI, Iczkowski KA. Basal cell carcinoma. In: Moch H, Humphrey PA, Ulbright TM, Reuter VE, (eds). WHO Classification of of Tumours of the Urinary System and Male Genital Organs. 4th edn. Lyon, France: International Agency for Research on Cancer (IARC); 2016. p. 171.

3. Ahuja A, Das P, Kumar N, Saini AK, Seth A, Ray R. Adenoid cystic carcinoma of the prostate: case report on a rare entity and review of the literature. Pathol Res Pract. 2011;207:391-4.

4. Ali TZ, Epstein JI. Basal cell carcinoma of the prostate: a clinicopathologic study of 29 cases. Am J Surg Pathol. 2007;31:697-705.

5. Bishop JA, Yonescu R, Epstein JI, Westra WH. A subset of prostatic basal cell carcinomas harbor the MYB rearrangement of adenoid cystic carcinoma. Hum Pathol. 2015;46:1204-8.

6. Chang K, Dai B, Kong Y, Qu Y, Wu J, Ye D, et al. Basal cell carcinoma of the prostate: clinicopathologic analysis of three cases and a review of the literature. World J Surg Oncol. 2013;11:193.

7. Cohen RJ, Goldberg RD, Verhaart MJ, Cohen M. Adenoid cystlike carcinoma of the prostate gland. Arch Pathol Lab Med. 1993;117:799-801.

8. Denholm SW, Webb JN, Howard GC, Chisholm GD. Basaloid carcinoma of the prostate gland: histogenesis and review of the literature. Histopathology. 1992;20:151-5.

9. Grignon DJ, Ro JY, Ordonez NG, Ayala AG, Cleary KR. Basal cell hyperplasia, adenoid basal cell tumor, and adenoid cystic carcinoma of the prostate gland: an immunohistochemical study. Hum Pathol. 1988;19:1425-33.

10. Iczkowski KA, Ferguson KL, Grier DD, Hossain D, Banerjee SS, McNeal JE, et al. Adenoid cystic/basal cell carcinoma of the prostate: clinicopathologic findings in 19 cases. Am J Surg Pathol. 2003;27:1523-9.

11. Komura $\mathrm{K}$, Inamoto $\mathrm{T}$, Tsuji $\mathrm{M}$, Ibuki $\mathrm{N}$, Koyama $\mathrm{K}$, Ubai $\mathrm{T}$, et al. Basal cell carcinoma of the prostate: unusual subtype of prostatic carcinoma. Int J Clin Oncol. 2010;15:594-600.

12. Mastropasqua MG, Pruneri G, Renne G, De Cobelli O, Viale G. Basaloid cell carcinoma of the prostate. Virchows Arch. 2003;443:787-91.

13. McKenney JK, Amin MB, Srigley JR, Jimenez RE, Ro JY, Grignon DJ, et al. Basal cell proliferations of the prostate other than usual basal cell hyperplasia: a clinicopathologic study of 23 cases, including four carcinomas, with a proposed classification. Am J Surg Pathol. 2004;28:1289-98.

14. Montironi R, Mazzucchelli R, Stramazzotti D, Scarpelli M, Lopez Beltran A, Bostwick DG. Basal cell hyperplasia and basal cell carcinoma of the prostate: a comprehensive review and discussion of a case with c-erbB-2 expression. J Clin Pathol. 2005;58:290-6.

15. Segawa N, Tsuji M, Nishida T, Takahara K, Azuma H, Katsuoka Y. Basal cell carcinoma of the prostate: report of a case and review of the published reports. Int J Urol. 2008;15:557-9.

16. Simper NB, Jones CL, MacLennan GT, Montironi R, Williamson $\mathrm{SR}$, Osunkoya AO, et al. Basal cell carcinoma of the prostate is an aggressive tumor with frequent loss of PTEN expression and overexpression of EGFR. Hum Pathol. 2015;46:805-12.

17. Tsuruta K, Funahashi Y, Kato M. Basal cell carcinoma arising in the prostate. Int J Urol. 2014;21:1072-3.

18. Mitani Y, Li J, Rao PH, Zhao YJ, Bell D, Lippman SM, et al. Comprehensive analysis of the MYB-NFIB gene fusion in 
salivary adenoid cystic carcinoma: Incidence, variability, and clinicopathologic significance. Clin Cancer Res. 2010; 16:4722-31.

19. West RB, Kong C, Clarke N, Gilks T, Lipsick JS, Cao H, et al. MYB expression and translocation in adenoid cystic carcinomas and other salivary gland tumors with clinicopathologic correlation. Am J Surg Pathol. 2011;35:92-9.

20. Brill LB 2nd, Kanner WA, Fehr A, Andren Y, Moskaluk CA, Loning T, et al. Analysis of MYB expression and MYB-NFIB gene fusions in adenoid cystic carcinoma and other salivary neoplasms. Mod Pathol. 2011;24:1169-76.

21. Fusco N, Geyer FC, De Filippo MR, Martelotto LG, Ng CK, Piscuoglio S, et al. Genetic events in the progression of adenoid cystic carcinoma of the breast to high-grade triple-negative breast cancer. Mod Pathol. 2016;29:1292-305.

22. North JP, McCalmont TH, Fehr A, van Zante A, Stenman G, LeBoit PE. Detection of MYB alterations and other immunohistochemical markers in primary cutaneous adenoid cystic carcinoma. Am J Surg Pathol. 2015;39:1347-56.

23. Kim J, Geyer FC, Martelotto LG, Ng CK, Lim RS, Selenica P, et al. MYBL1 rearrangements and MYB amplification in breast adenoid cystic carcinomas lacking the MYB-NFIB fusion gene. J Pathol. 2018;244:143-50.

24. Persson M, Andren Y, Mark J, Horlings HM, Persson F, Stenman G. Recurrent fusion of MYB and NFIB transcription factor genes in carcinomas of the breast and head and neck. Proc Natl Acad Sci USA. 2009; 106:18740-4.
25. Andersson MK, Afshari MK, Andren Y, Wick MJ, Stenman G. Targeting the oncogenic transcriptional regulator MYB in adenoid cystic carcinoma by inhibition of IGF1R/AKT signaling. J Natl Cancer Inst. 2017;109. https://doi.org/10.1093/jnci/djx017.

26. Ho AS, Kannan K, Roy DM, Morris LG, Ganly I, Katabi N, et al. The mutational landscape of adenoid cystic carcinoma. Nat Genet. 2013;45:791-8.

27. Wysocki PT, Izumchenko E, Meir J, Ha PK, Sidransky D, Brait M. Adenoid cystic carcinoma: emerging role of translocations and gene fusions. Oncotarget. 2016;7:66239-54.

28. Brunelli M, Eble JN, Zhang S, Martignoni G, Cheng L. Metanephric adenoma lacks the gains of chromosomes 7 and 17 and loss of $\mathrm{Y}$ that are typical of papillary renal cell carcinoma and papillary adenoma. Mod Pathol. 2003;16:1060-3.

29. Gobbo S, Eble JN, Maclennan GT, Grignon DJ, Shah RB, Zhang $\mathrm{S}$, et al. Renal cell carcinomas with papillary architecture and clear cell components: the utility of immunohistochemical and cytogenetical analyses in differential diagnosis. Am J Surg Pathol. 2008;32:1780-6.

30. Jones TD, Eble JN, Wang M, MacLennan GT, Delahunt B, Brunelli $\mathrm{M}$, et al. Molecular genetic evidence for the independent origin of multifocal papillary tumors in patients with papillary renal cell carcinomas. Clin Cancer Res. 2005; 11:7226-33.

31. Cheng L, Zhang S, Wang L, MacLennan GT, Davidson DD. Fluorescence in situ hybridization in surgical pathology: principles and applications. J Pathol Clin Res. 2017;3:73-99. 